University of Nebraska - Lincoln

DigitalCommons@University of Nebraska - Lincoln

1983

\title{
Avian Associations of the Northern Great Plains Grasslands
}

Harold A. Kantrud

USGS Northern Prairie Wildlife Research Center

Russell L. Kologiski

USGS Northern Prairie Wildlife Research Center

Follow this and additional works at: https://digitalcommons.unl.edu/usgsnpwrc

Part of the Other International and Area Studies Commons

Kantrud, Harold A. and Kologiski, Russell L., "Avian Associations of the Northern Great Plains Grasslands" (1983). USGS Northern Prairie Wildlife Research Center. 177.

https://digitalcommons.unl.edu/usgsnpwrc/177

This Article is brought to you for free and open access by the US Geological Survey at DigitalCommons@University of Nebraska - Lincoln. It has been accepted for inclusion in USGS Northern Prairie Wildlife Research Center by an authorized administrator of DigitalCommons@University of Nebraska - Lincoln. 


\title{
Avian associations of the northern Great Plains grasslands
}

\author{
HAROLD A. KANTRUD and RUSSELL L. KOLOGISKI* U.S. Fish and Wildlife Service, \\ Northern Prairie Wildlife Research Center, Jamestown, North Dakota 58401, U.S.A.
}

\begin{abstract}
The grassland region of the northern Great Plains was divided into six broad subregions by application of an avian indicator species analysis to data obtained from 582 sample plots censused during the breeding season. Common, ubiquitous species and rare species had little classificatory value and were eliminated from the data set used to derive the avian associations. Initial statistical division of the plots likely reflected structure of the dominant plant species used for nesting; later divisions probably were related to foraging or nesting cover requirements based on vegetation height or density, habitat heterogeneity, or possibly to the existence of mutually similar distributions or shared areas of greater than average abundance for certain groups of species. Knowledge of the effects of grazing, mostly by cattle, on habitat use by the breeding bird species was used to interpret the results of the indicator species analysis. Moderate grazing resulted in greater species richness in nearly all subregions; effects of grazing on total bird density were more variable.
\end{abstract}

\section{Introduction}

In a summary of the development of the field of biogeography and its limitations, Rotramel (1973) emphasized the need to define biogeographic areas in an ecologic context. Both he and Peters (1955) questioned the usefulness of biogeographic studies conducted across steep environmental gradients where distinct breaks in the landscape preclude the separation of physiographic factors influencing species distributions from others such as those associated with climate and altitude. Two other conditions that should be met within a study area before useful biogeographic boundaries can be drawn are the existence of range limits and contagious species distributions (Hagemeier \& Stults, 1964). Lack of information on abundance within range may also limit the usefulness of biogeographical studies (Bock, Bock \& Lepthien, 1977). Our

* Present address: U.S. Fish and Wildlife Service, Box 1036, Albuquerque, New Mexico 87103, U.S.A. information on breeding birds in the Great Plains of North America indicated that these prerequisites were met and that the data set would suffice to test for the presence of avian biogeographical boundaries within this vast, relatively homogeneous region.

The northern Great Plains corresponds to the Saskatchewan biotic province of Dice (1952). It is mostly grassland characterized by low relief, fairly similar soils, and a strongly continental climate. These factors plus a history of fires, grazing, and in a major portion of the region, glaciation, have resulted in a relatively species-poor flora. Significant changes in species composition of the dominant plants in major grassland plant associations may occur over distances measured only in hundreds of kilometres. Modern sampling methods have not been used to divide the region into phytogeographic subregions. Similarly, no systematic attempt has been made to classify avian associations of the northern Great Plains grasslands. General 


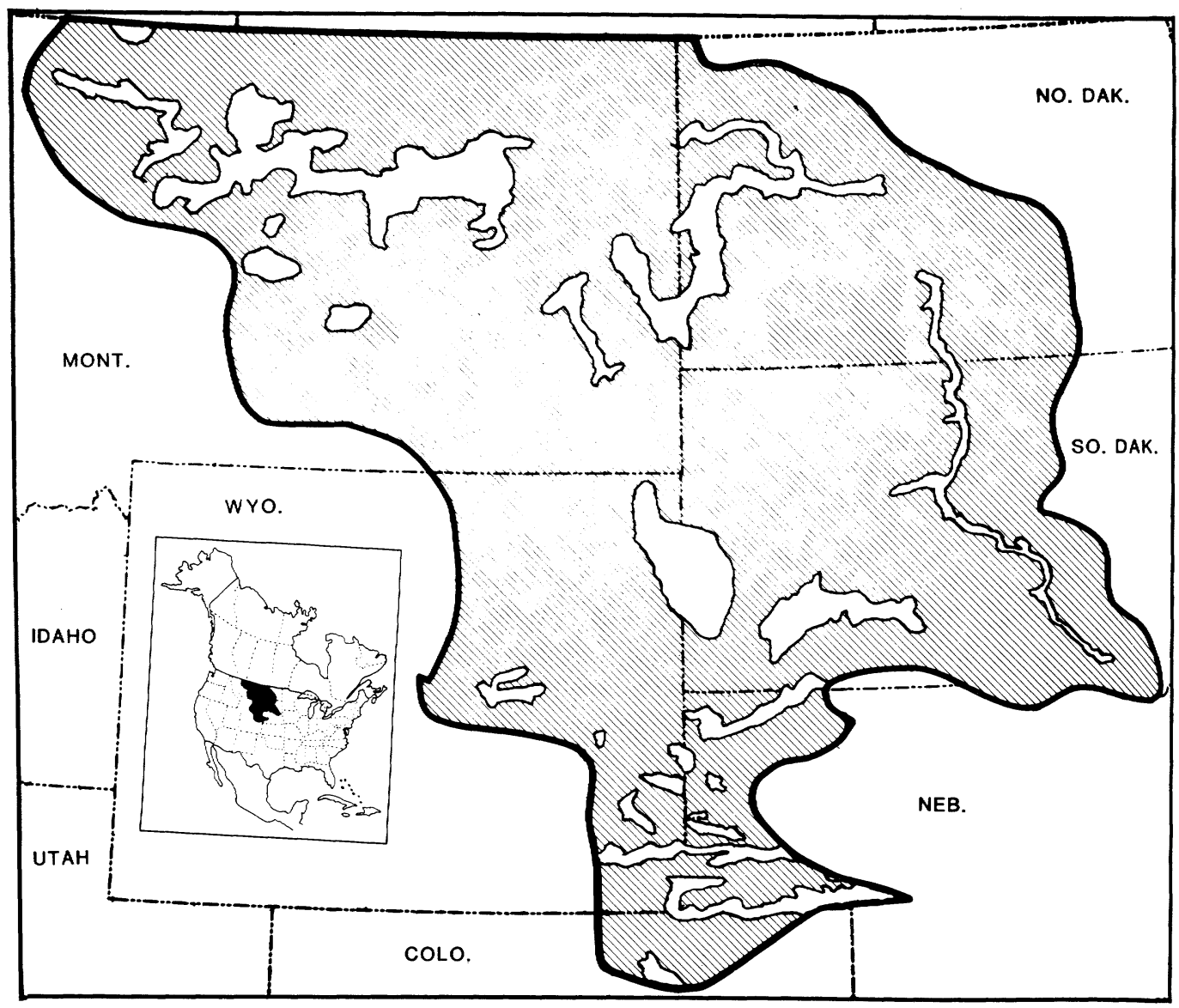

FIG. 1. Outline of northern Great Plains study area. Inset shows position of study area on North American continent. Study area boundaries are as follows: north: border between United States and Canada; east: eastern edge of Missouri Coteau (modified slightly from Fenneman, 1931); south: Keya Paha River, Niobrara River, Nebraska Sandhills, and South Platte River; west: western edge of Great Plains as mapped by Aandahl (1972). Areas (in white) within study area were not sampled (see text; from Kantrud \& Kologiski, 1982).

classifications such as that by Visher (1916) for the region, and for several of the various included states (Visher, 1918; Saunders, 1921; Stewart, 1975), have listed characteristic birds of various grassland plant associations or vegetative structural types, but these classifications were not based on statistical sampling.

In the present report we describe and map avian associations that occur in the northern Great Plains grasslands during the breeding season. These associations are based on application of a polythetic, divisive, two-way indicator species analysis of quantitative data derived from a large number of sample plots.
Knowledge of the variable effects of grazing on the species composition and density of birds in various areas of the Great Plains was necessary to interpret the results of the analysis.

Field studies were conducted on 615 plots of uncultivated upland native grassland and shrubsteppe during late spring and early summer in 1974-78 in the portion of the northern Great Plains that lies within the United States (Fig. 1). The study area (about $600,000 \mathrm{~km}^{2}$ ) includes portions of Montana, Wyoming, Colorado, North Dakota, South Dakota and Nebraska. Grasslands in the mountains, badlands, sand deposits, and river valleys (shown 
in white on Fig. 1) were not sampled and so are excluded from further consideration. A photograph of a study plot within each subregion is provided (Figs. 7-12).

We have earlier analysed the effects of grazing and soils on the use of these plots by birds (Kantrud \& Kologiski, 1982). The methods we used to select the sample units, conduct bird censuses, stratify soils, and estimate grazing intensity are repeated here for the reader's convenience.

\section{Methods}

\section{Selection of sample units}

Several methods were used to select the sample plots (Fig. 2). In 1974, plots were selected in numbers proportional to the sizes of the areas of the several mapped physio- graphic landforms in North Dakota (U.S. and North Dakota Geological Survey maps). Avian use of grasslands developed over these landforms in North Dakota has been reported (Kantrud, 1981), but only the plots lying within the Great Plains are included in the present study. Sample unit locations were initially selected at random from numbered legal townships $\left(93.2 \mathrm{~km}^{2}\right)$, sections (259 ha) and quarter-sections (65 ha). However, differential rates of agricultural disturbance of grasslands among the landforms prevented the maintenance of randomness. If a selected area was devoid of native grassland, the nearest usable plot was chosen. Many plots were rejected because field examination revealed old furrows, rock piles, plantings of domestic grass, or other evidence of past cultivation. Although most of the plots studied in 1974 were legal quarter-sections (65 ha), several

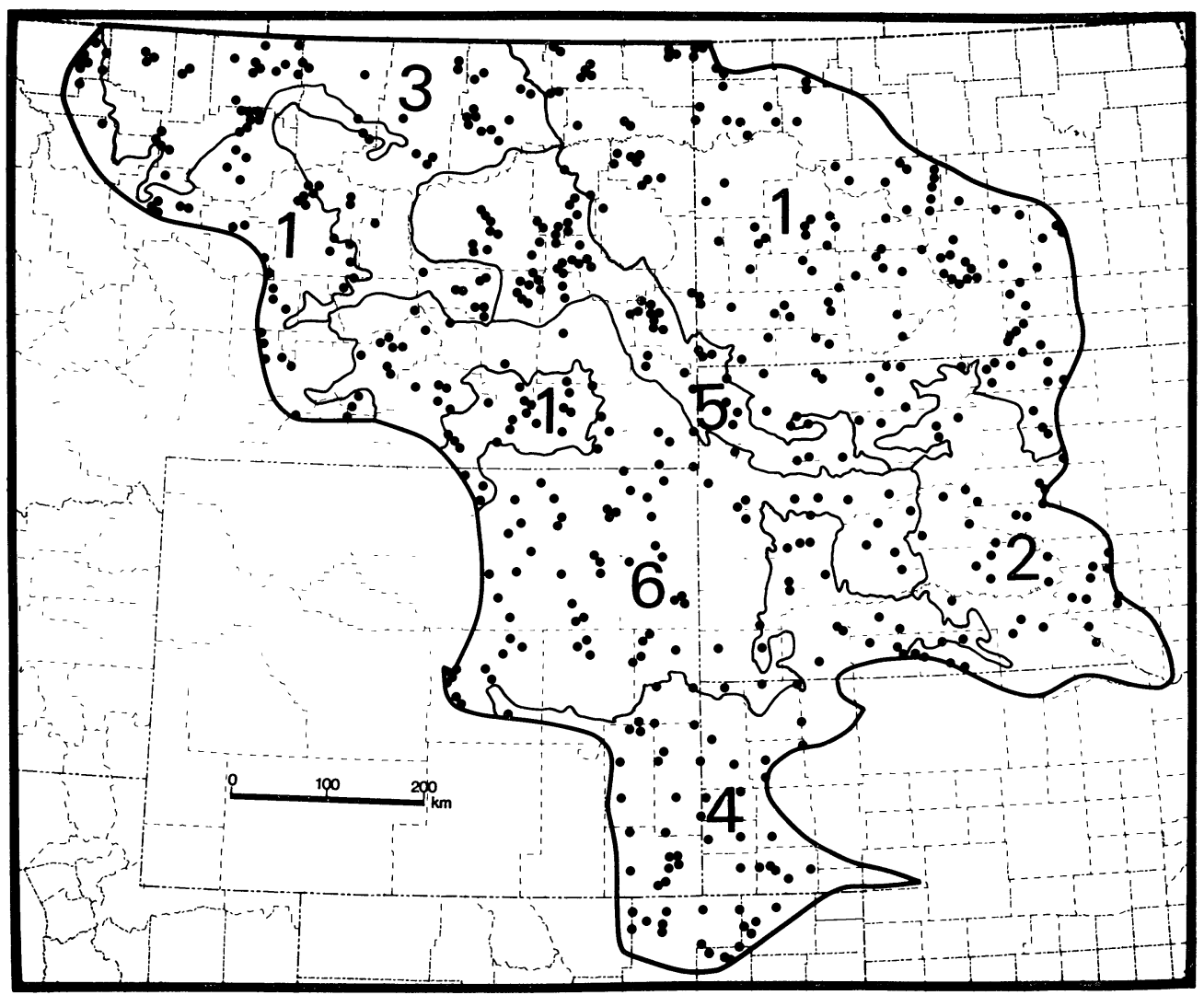

FIG. 2. Location of soils (Aandahl, 1972) and sample plots. Some dots represent more than one plot. Soils coded as follows: 1 - typic borolls; 2 - typic ustolls; 3 - aridic borolls; 4 - aridic ustolls; 5 borollic Aridisols; 6 - ustic Aridisols (see text; from Kantrud \& Kologiski, 1982). 


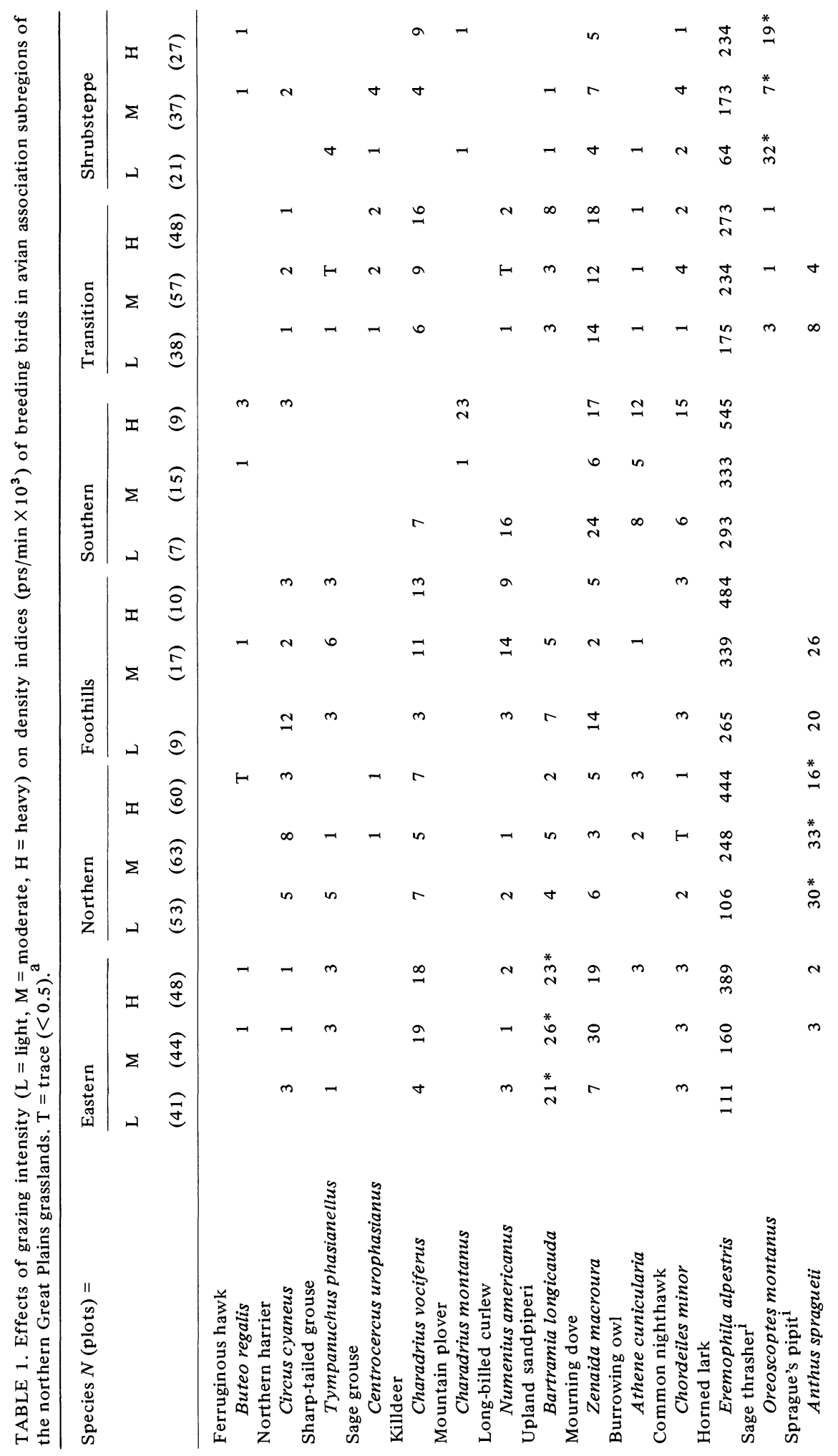




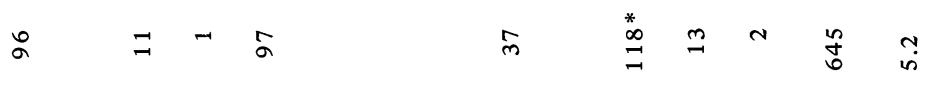

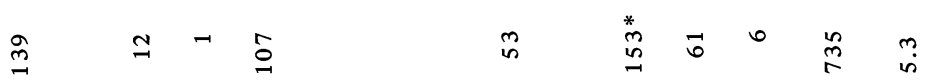

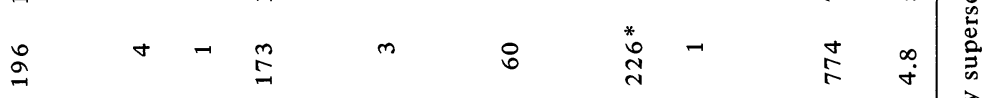

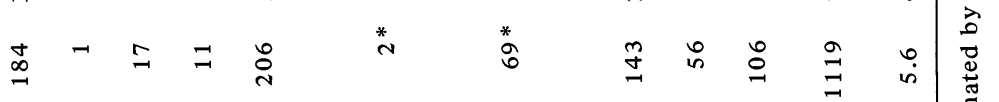

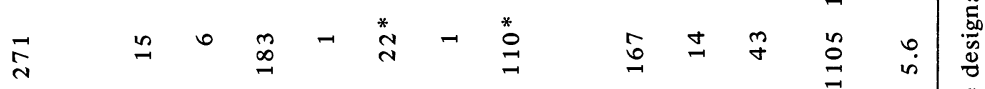

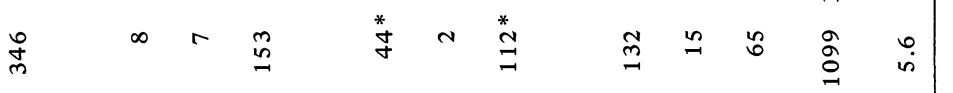

$$
\begin{aligned}
& \text { \& } \\
& 8 \quad \infty
\end{aligned}
$$

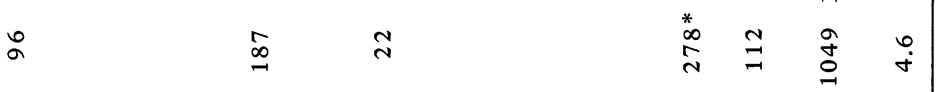

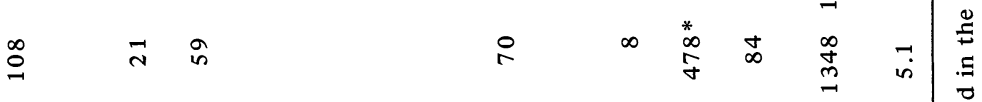

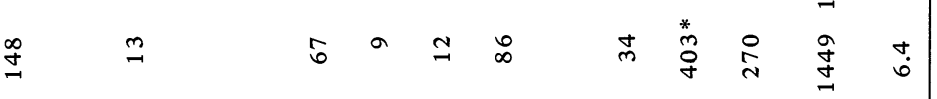

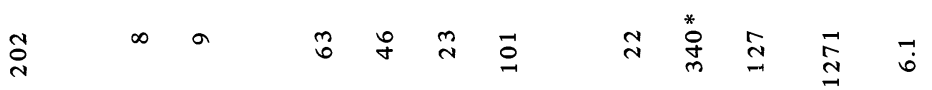

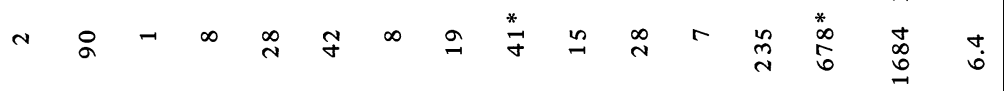

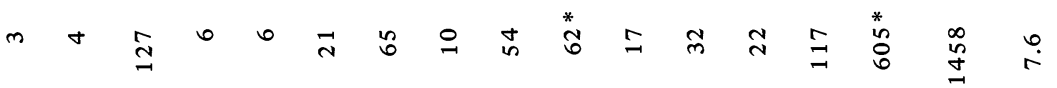

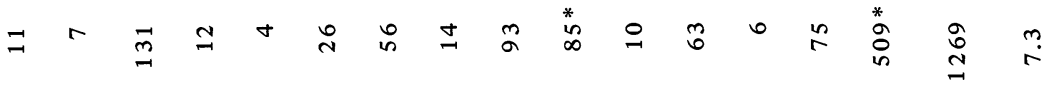

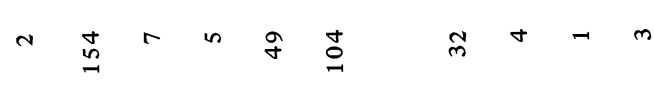

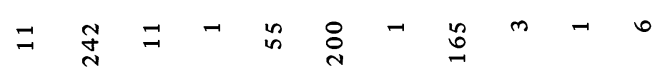

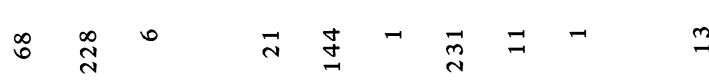

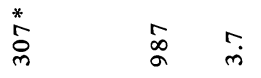

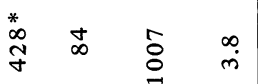

$$
\begin{aligned}
& \begin{array}{l}
0 \\
0 \\
0 \\
0 \\
0 \\
0 \\
0 \\
0 \\
0 \\
0 \\
.0 \\
.5 \\
0
\end{array}
\end{aligned}
$$


were as large as a section or as small as 16 ha. Most plots were square, but occasionally it was necessary to use odd-shaped areas.

In 1975, in Montana and Wyoming, sample units were randomly selected from consecutively numbered townships, in proportion to the area of grassland types mapped by Küchler (1964). After a township was selected and found to lie entirely within the Küchler type, one of a set of twenty-seven possible clusters of four quarter-sections within the township was selected at random. In the field, the usable quarter-section nearest to each of the four cluster elements was censused.

In 1976, in Colorado, Montana, Nebraska and South Dakota, single quarter-section sample units were selected in proportion to the areas of grassland types 64,65 and 66 of Küchler (1964). Acceptable plots nearest to the southwest corner of every eighth township in South Dakota and every fourth township in the other states were censused.

In 1977 and 1978 the entire study area was sampled. Quarter-section sample units were subjectively chosen in numbers proportional to the areas of major soil groups mapped by Aandahl (1972).

On a local scale, grasslands not considered typical of general area soils were rejected. These included expanses of wet meadow and rocky hilltops.

\section{Bird censuses}

A single bird census was conducted on each plot at times between sunrise and sunset when temperatures did not exceed $32^{\circ} \mathrm{C}$, precipitation did not occur, and sustained wind velocities did not exceed $24 \mathrm{~km} / \mathrm{h}$. Field work was conducted by two teams, each consisting of a botanist and an ornithologist. Census dates were as follows: 1974: 22 May to 19 July; 1975: 29 May to 18 July; 1976: 23 May to 14 July; 1977: 24 May to 13 July; 1978: 22 May to 2 July.

Comparison of five 3 -h time periods (06.00-21.00hours) in our study showed that: (1) of twenty-nine species censused, peak densities for one or more species occurred during each of the five periods; (2) peak densities for eleven species occurred during the 09.00-12.00 hours period; and (3) observed total density decreased by up to $25 \%$ during counts conducted after the 06.0009.00 hours period. Temporal variation in bird counts undoubtedly biased density indices for some species, but was not considered a serious problem because of its random nature as applied to our censuses.

Analyses based on single bird censuses are not recommended during intensive studies where population estimates are required. Nevertheless, they have been used successfully to derive indices to populations or multispecies diversity measurements during extensive surveys (Robbins \& Van Velzen, 1967; Stewart \& Kantrud, 1972; U.S. Department of Interior and Canadian Department of Environment, 1977; Rotenberry, 1978; Kantrud, 1981). Speirs \& Orenstein (1967) showed that average efficiency of single censuses in open Ontario habitats is only $66-76 \%$ that of six to ten temporally spaced censuses in estimating breeding populations, but we felt justified in basing indices to bird density on single counts in the grassland habitats because most of the species have behavioural adaptations including lengthy, loud, and often elaborate flight songs, perch songs, and synchronous display - that tend to increase greatly their detectability compared with birds inhabiting wooded areas Furthermore, birds are also rather easily flushed in grasslands. In addition, the large areas of the sample plots resulted in relatively high absolute numbers of bird observations per plot.

We attempted to compensate for phenological differences across the northern Great Plains by beginning the surveys in southerly areas of low elevation. As the breeding season progressed, we moved to regions of successively high latitude and elevation.

All species were identified in the field by sight or sound. Counts were based primarily on numbers of pairs as indicated by territorial males or segregated pairs. Each male blackbird (polygynous) or brown-headed cowbird (promiscuous) was considered to represent a pair. Single raptors, grouse, shorebirds and nighthawks observed on a sample plot were considered to represent a pair, but if more than one was seen the total was halved and rounded to the nearest lower integer. Additional details on determinations of breeding status were described by Stewart \& Kantrud (1972). Bird names, which are from the 
checklist of the American Ornithologists' Union (1957) and its several supplements, are shown in Table 1.

The 'hollow square' technique of Speirs \& Orenstein (1967) was used on the standard 65 ha plots; the $1609 \mathrm{~m}$ transect route lay $202 \mathrm{~m}$ inside the boundary (Fig. 3). Birds were counted within $101 \mathrm{~m}$ of the route, yielding an areal coverage of 31.5 ha. We considered $101 \mathrm{~m}$ well within our detection

\section{Census Transect $(1609 \mathrm{~m})$}

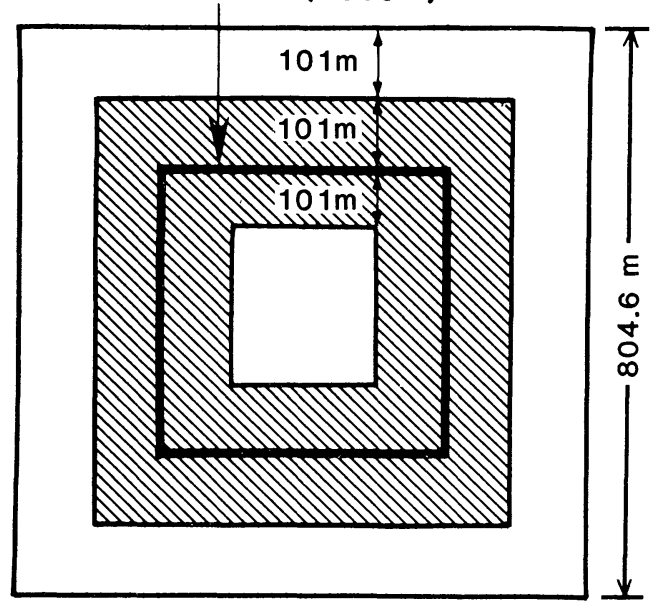

65 ha Square (quarter section)

FIG. 3. Quarter-section sample plot showing transect route (heavy line). Shaded area censused $=31.5$ ha (see text; from Kantrud \& Kologiski, 1982).

distance for all species censused. Transect routes were variable on the few plots of other sizes and shapes. The verges of many plots bordered other habitat types. To reduce the influence on the counts of birds occupying fencelines or adjacent habitats, we restricted census transects to the interior of each plot, except for the few plots $<65$ ha in area.

Transects were walked at a standard speed of $40 \mathrm{~m} / \mathrm{min}$. To allow standardization of data from plots or transects of unequal size and shape, expression of bird density in units of time has been used in similar extensive studies (e.g. Grinnell \& Storer, 1924; Skinner, 1975). So, our indices to bird density were expressed in pairs $/ \min \times 10^{3}$.

\section{Soils}

Soils in the eastern part of the study have accumulated more organic material than those in the west (excluding the foothills) because of greater annual precipitation, lower soil temperature, and greater percentage of precipitation that occurs during the growing season. Parent materials underlying soils over most of the northern Great Plains are residuum from relatively old marine and continental sediments, but soils in portions of the Dakotas and northern Montana have developed over more recent glacial sediments (Bluemle, 1977). Topographic relief is low over most of the study area; it probably was not a significant factor in the development of the major soils that now occur there.

A flexible, hierarchical system of soil taxonomy has been developed for the United States (U.S. Soil Conservation Service, 1975) and is used here. Upland soils of the study area are primarily of two orders, the Mollisols and Aridisols. Mollisols are characterized by dark-coloured surface horizons that are rich in organic matter and contain adequate moisture to support stands of perennial grasses and other mesophytes (Fig. 4). Aridisols are light-coloured soils, low in organic carbon, with moisture regimes suited to xerophytes. The six soils on which the study plots were located (Fig. 2) correspond to combinations of soil suborders and great groups mapped and classified by Aandahl (1972). The soils are based primarily on combinations of soil temperature, moisture content, and organic matter content (Fig. 4). For convenience, we named the soils after the major suborder in the categories mapped by Aandahl (1972); other closely related soil taxa occur within the areas shown in Fig. 2.

\section{Grazing intensity}

We estimated grazing intensity by comparing the percentage of bare soil, amount of standing and fallen dead vegetation, and average vegetative height on the study plots with that of nearby protected or ungrazed areas. On the basis of this information, we placed plots into the three subjective categories of heavily, moderately and lightly grazed. Distribution of the 615 plots among grazing intensities was as follows: heavy, 197; moderate, 241; and light, 177. Any plots lacking evidence of livestock use were not censused. Most of the plots were grazed 


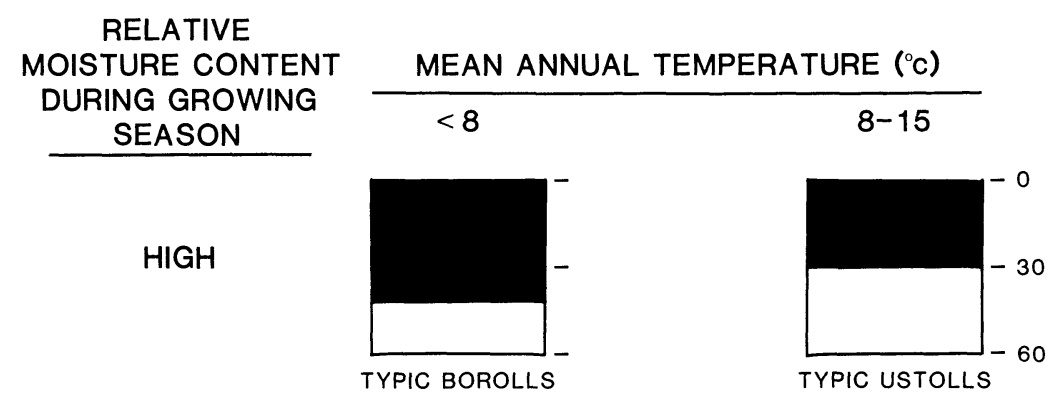

MODERATE
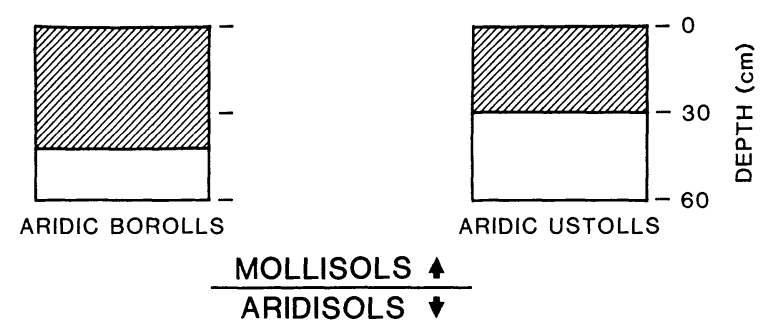

LOW
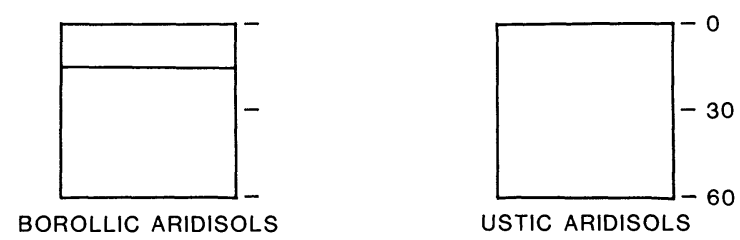

FIG. 4. Highly generalized 'profiles' of the soil groups mapped by Aandahl (1972) based on major differentiae (U.S. Soil Conservation Service, 1975). Degree of shading and thickness of the upper layer is intended to portray colour (chroma) and relative depth of horizons that contain significant amounts of organic carbon. All 'profiles' represent a $60 \mathrm{~cm}$ thick vertical section (see text; from Kantrud \& Kologiski, 1982).

by cattle but a few were used for sheep, bison or horses. A few plots contained various combinations of domestic livestock and horses. Plots in each grazing category were well distributed among the strata.

\section{Data analysis}

We derived the avian associations by interpretation of the results of two-way indicator species analysis (Hill, 1979), a polythetic divisive method based on reciprocal averaging ordination (Hill, 1973). This method classifies species as well as stands and is considered an improvement on the original indicator species analysis of Hill, Bunce \& Shaw (1975). We used the computer program TWINSPAN developed for this method by Hill (1979).
Indicator species analysis is similar to traditional European methods for ordering speciesby-stand phytosociological tables (see MuellerDombois \& Ellenberg, 1974, Chapter 9).

The basic function of TWINSPAN is to develop successive dichotomies from a data set. The dichotomies are determined by differential species, which are preferential to one side or the other, of a crude initial dichotomy based on reciprocal averaging. The dichotomies are also characterized (but not determined) by indicator species, differentials that exhibit strong ecological preferences and are sufficiently common in groups of stands to characterize them. For organizational purposes only, each dichotomy has a positive and a negative side; therefore, there are positive and negative preferentials. Species showing no 
preference are termed non-preferentials. The use of indicator and preferential species will be discussed in the Results section.

Two-way indicator species analysis was chosen to derive the avifaunations primarily because of its objective nature, applicability to large sets of quantitative data (Hill, 1979), and our successful experiments with the technique on well known data sets.

Abundant, ubiquitous species have no classificatory value for delineation of biogeographical areas because range limits must occur (Peters, 1955; Hagemeier \& Stults, 1964; Rodgers, Owen \& Homewood, 1982) so these species were excluded from the TWINSPAN analysis. We mapped the distribution of all twenty-nine species censused and selected twelve (Table 1) which best met the criteria for the indicator species analysis. This procedure reduced the number of plots for analysis from 615 to 582 because thirtythree plots contained only abundant, uniquitous species. These thirty-three plots were scattered throughout the study area, which indicated they did not represent a separate avian association.

After initial mapping of the TWINSPANgenerated groups, we removed some obviously outlying (isolated plots lying $>50 \mathrm{~km}$ outside our drawn boundaries) sample plots to reduce implied accuracy and confusing interdigitation of the mapped boundaries. An additional basis for the exclusion of these plots was that they probably represented disjunct patches of habitat that attracted small numbers of birds not typical of the general area in which they fell. For the plotting of species ranges, MacArthur (1972) thought it useful to use the point at which density fell to $1 / 20$ of that at centre or maximum. The plots we removed never exceeded $10 \%$ of the total plots in any of the groups derived from the analysis. These plots were retained for tabulating the species composition and abundance of birds within the other subregions in which they fell. Tabulations for subregions do not include plots from other subregions that occurred in areas of overlap. Plots containing only ubiquitous species were also included in the tabulations. These were assigned to the subregions in which they fell; in areas of overlap they were assigned to all included subregions.

\section{Results and Discussion}

\section{Derivation of avian association subregions}

Rotramel (1973) emphasized the necessity of gathering biogeographical data over a broad array of field stations and stressed the importance of interpreting information on species ecologies in a geographic context to reveal factors that limited their distribution. The desirability of obtaining data from a large number of stations perhaps led most zoogeographers to describe faunations (Udvardy, 1969) on the basis of distributional data because they existed in large amounts in faunas and specimen collections. However, the desirability of quantitative information in community studies or for biogeographic mapping has long been recognized (Dice, 1930; Cain, 1947; Udvardy, 1963). Frenkel \& Harrison (1974) stated that biogeographical data collected in quantitative form would be especially useful where assessment of lands for grazing potential was being considered. Here we will attempt to show that several avian associations exist within the northern Great Plains grasslands but that their recognition may require knowledge of the ecologies of the species, especially differences in their use of various physiognomic or structural types of vegetation and their reaction to herbage removal by livestock.

We judged the validity of the associations derived from the two-way indicator species analysis primarily on the basis of differences in species composition and spatial separation of the grouped plots. However, ecological attributes of all preferential species, especially differences in habitat use as related to the effects of grazing on the various types of grasslands within the study area, were also of great value. These may have revealed some of the major factors governing the distribution and abundance of open-country birds at the regional scale. The effects of grazing on the species composition and density of birds within the subregions are given later.

(a) Level 1. The first level division of 582 sample plots distinguished 365 plots (group 1) with high indicator scores for grasshopper sparrow, Baird's sparrow, and chestnutcollared longspur and 217 plots (group 2) with high indicator scores for sage thrasher, 


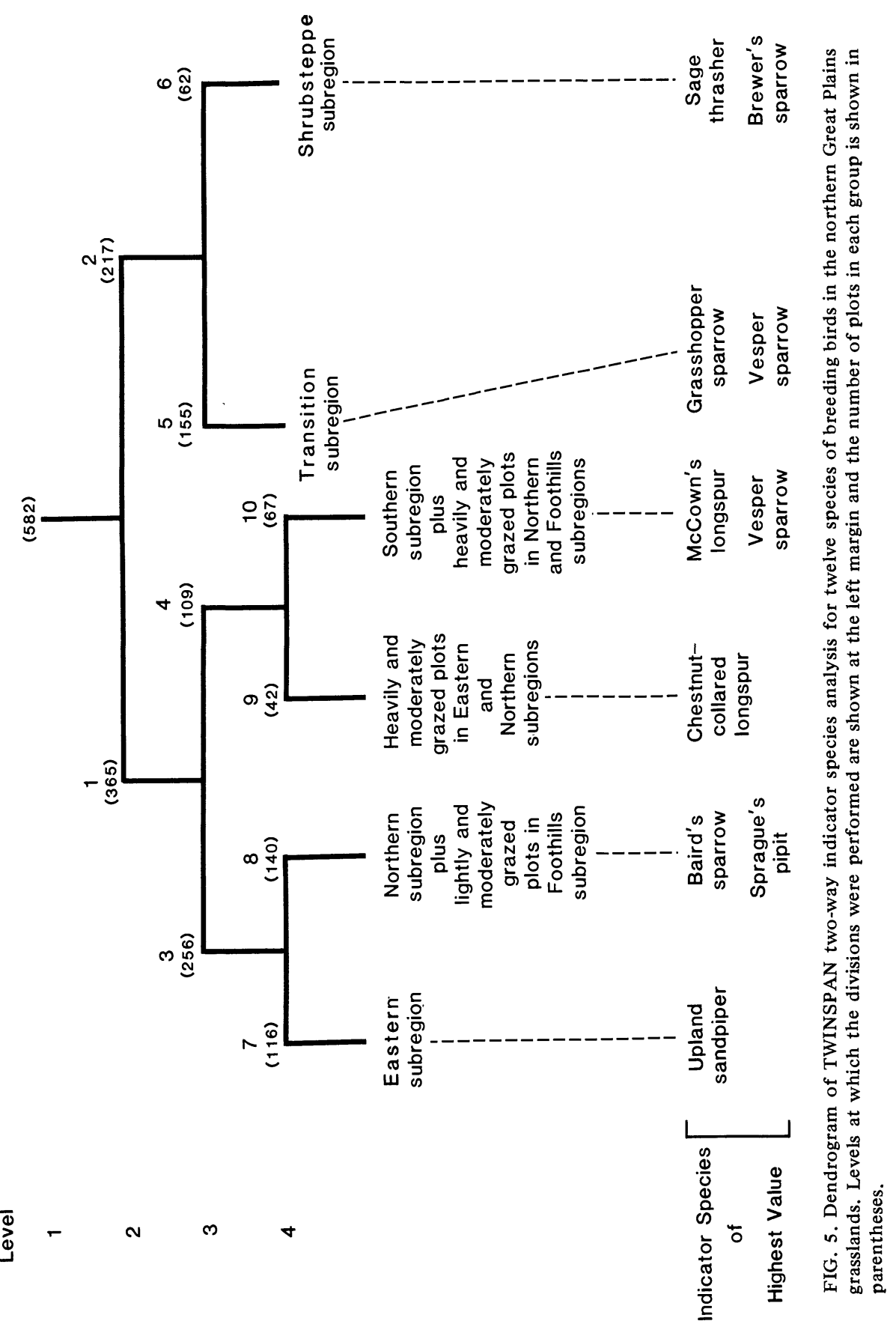


vesper sparrow, and Brewer's sparrow (Fig. 5). Spatially, it was clear that the division separated the relatively shrubless grasslands of northeastern Colarado, southeastern Wyoming, northwestern Nebraska, the Dakotas, and northern Montana (group 1) from the shrubby grasslands (shrubsteppe) of central and northern Wyoming and southcentral Montana (group 2).

The mathematical associations of species at level 1 probably reflected common affinities for the structural types of vegetation used for nesting: all indicator and preferential species for group 1 nest on the ground in grassland. In addition to the indicator species, preferential species for this group were upland sandpiper, Sprague's pipit and McCown's longspur. Conversely, two of the three indicator species for the shrubsteppe group nest in or underneath the canopy of shrubs, and the third, vesper sparrow, nests both on or above the ground in grassland or shrubsteppe, but reaches highest density in shrubsteppe (Table 1). Grazing obviously was not a factor in this dichotomy because the proportion of lightly, moderately and heavily grazed plots in each group was similar to that of the entire sample. More intensive studies (Rotenberry \& Wiens, $1978,1980)$ have shown that the avian guild of the Artemisia-dominated shrubsteppe remains ecologically distinct even when compared with a greater number of habitat types than we studied.

(b) Level 2. Group 1 (Fig. 5) was divided into 256 plots (group 3) indicated by highest scores for grasshopper sparrow, Baird's sparrow, upland sandpiper, Sprague's pipit and clay-coloured sparrow, and 109 plots (group 4) indicated by highest score for McCown's longspur. There was great spatial congruity between these two groups, which indicated they did not represent true zoogeographic areas, but within-region differentiation.

Placement of species in these two groups by the TWINSPAN program can probably be related in turn to nesting or foraging cover preferences: group 4 indicator, McCown's longspur, prefers to nest and forage in various associations of shortgrass prairie or other, naturally taller grassland types rendered short by grazing. Conversely, all indicator species for group 3 usually prefer taller or denser vegetation. A large proportion $(82 \%)$ of the plots in group 4 were heavily or moderately grazed, contrasted to $63 \%$ for group 3 , which indicated that these groups probably reflected the combined effects of grazing and the occurrence of naturally short types of grassland.

Level 2 division of the 217 plots in shrubsteppe resulted in two avian associations that we considered valid. Group 5 (Fig. 5) had 155 plots; highest indicator scores for the group were attained by vesper and grasshopper sparrows. In group $6 \quad(n=62$ plots $)$, sage thrasher and Brewer's sparrow had highest scores. The two groups differed spatially: group 6 generally occupied a core area which extended into the study area from central Wyoming and group 5 was mostly peripheral to the area of group 6, occupying portions of the western Dakotas, eastern Wyoming, and a large area of southeast, southcentral and central Montana.

Groups 5 and 6 probably reflected differences in habitat heterogeneity. Group 6 plots evidently represented the nearly homogenous area of tall, dense black sage (Artemisia tridentata) that extends northeasterly into the Great Plains from the Wyoming Basin (Fenneman, 1931). Sage thrasher and Brewer's sparrow, which achieved highest indicator scores for group 6, usually nest above-ground and use this shrub extensively. A ground and a shrub-or-ground nester had highest indicator scores in group 5, probably because the area occupied by this group of plots supported a patchier habitat of mixed stands of shrubs and grasses. We considered this area transitional between shrubsteppe and 'pure' grassland. A. tridentata is also an important shrub in this area but assumes a shorter growth form there than in the area of group 6. Although of no indicator value because of low density, Brewer's sparrow occurred in $72 \%$ of the plots in group 5, attesting to the attractiveness of this transitional zone to at least one species that usually nests above ground level. Grazing probably was not a factor in the differentiation of these groups because the proportion of lightly, moderately, and heavily grazed plots within groups was similar. Areas occupied by groups 5 and 6 were considered to contain valid avian associations and have been termed the Transition and Shrubsteppe subregions (Fig. 6). 
Cluster analysis of data from sixty breeding bird transects in the Pacific Northwest has shown that sage thrasher and Brewer's sparrow are included in a bird community characteristic of the Artemisia-dominated shrubsteppe (Rotenberry \& Wiens, 1978). Interestingly, the abundant, though less habitatspecific vesper sparrow was missing from this cluster, much in the same manner as it lost its indicator value for 'pure' shrubsteppe at level 2 of our analysis.

(c) Level 3. Four avian associations (Eastern, Northern, Foothills and Southern subregions) were selected from third level divisions on the grassland 'side' of the two-way indicator species analysis. The 256 plots in group 3 (Fig. 5) were divided into group $7(n=116)$, that showed highest indicator score for upland sandpiper, and group $8 \quad(n=140)$ that was most strongly indicated by Baird's sparrow and Sprague's pipit. Geographically, the bulk of group 8 plots occupied almost all of the study area within North Dakota and large portions of northeastern and northcentral Montana. Some additional plots in this group fell in the foothills of the Rocky Mountains. These plots will be considered later. Group 7 plots occurred mostly in northwestern Nebraska, South Dakota, and southcentral and central North Dakota. Substantial spatial overlap between the two groups occurred in North Dakota. Among group 7 plots, grazing intensities were proportionally similar to the sample as a whole; in group 8 moderately and lightly grazed plots were more numerous.

TWINSPAN sep?ration of groups 7 and 8

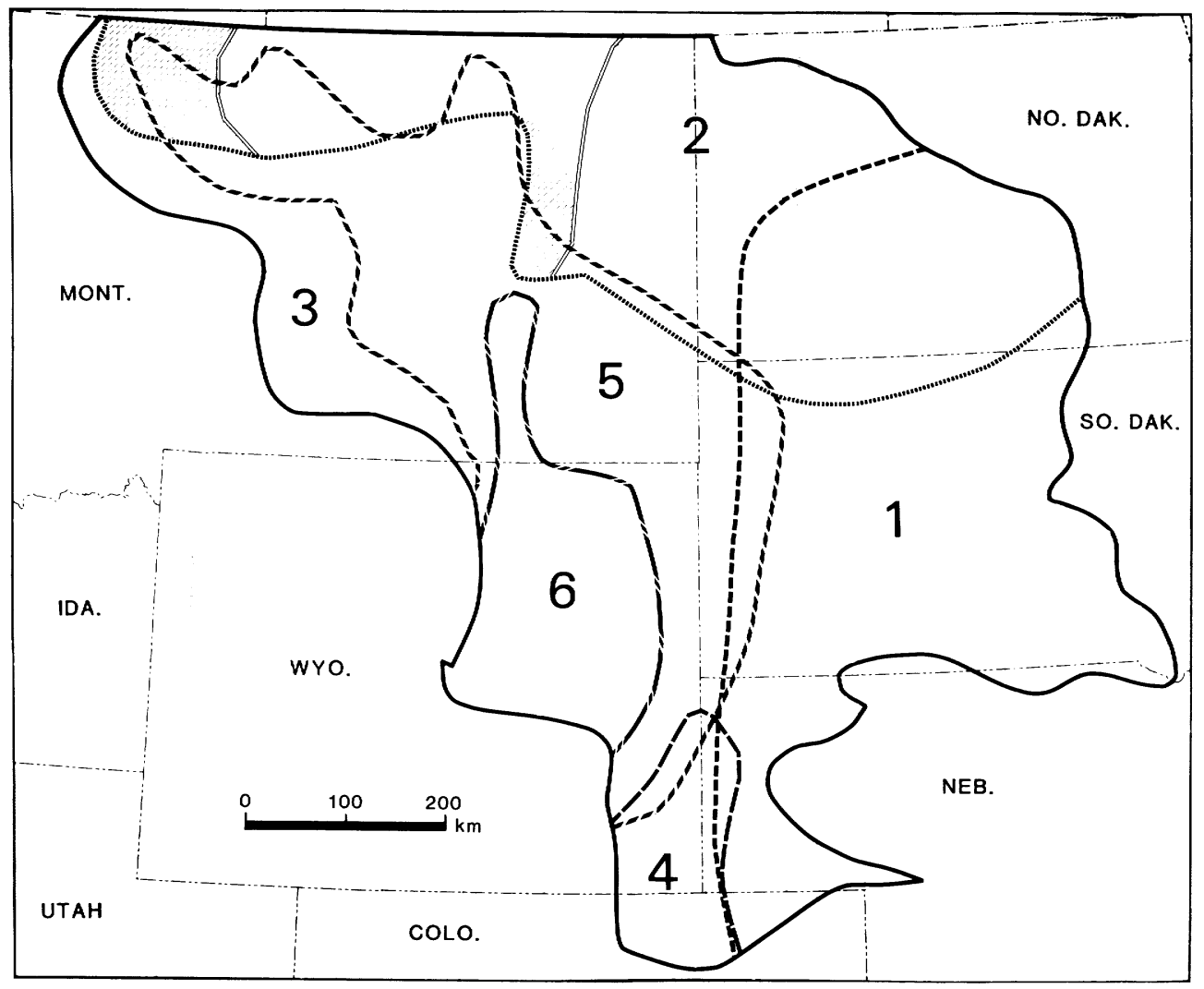

FIG. 6. Avian association subregions in the United States portion of the northern Great Plains grasslands derived from indicator species analysis. Subregion names as follows: 1: Eastern; 2: Northern; 3: Foothills; 4: Southern; 5: Transition; 6: Shrubsteppe. McCown's and chestnut-collared longspur densities varied greatly under heavy or moderate grazing in the Northern subregion; cross-hat ched areas tended to be dominated by McCown's, both species were about equally represented in the uncross-hatched area between the double-line symbols, and only the chestnut-collared was well represented in the remainder of the subregion. 
seemed to be related to mutually similar distributions or shared areas of species abundance. Baird's sparrow and Sprague's pipit, the two best indicator species in group 8 , have very similar ranges and areas of abundance in the study area (Kantrud, 1982). Upland sandpiper, although not restricted to the areas of group 7, reaches far greater abundance there along with other members of the avifauna we studied, including bobolink and grasshopper sparrow (Table 1). Areas occupied by plots in groups 7 and 8 were considered to contain valid associations, and were termed the Eastern and Northern subregions (Fig. 6).

Level 3 division of the group 4 plots $(n=$ 109) resulted in the recognition of two avian associations. Group $9(n=42)$ was indicated by chestnut-collared longspur. This group encompassed nearly all of the area covered by the Eastern and Northern subregions. Native grasslands in this area become most attractive to chestnut-collared longspur when herbage removal is significant (Table 1 and Kantrud \& Kologiski, 1982). Therefore, group 9 plots were assigned to either the Eastern or Northern subregions, or both in the area of spatial overlap.

The sixty-seven plots in group 10 were indicated by high scores for McCown's longspur. These plots were divided among three distinct geographical areas and, on the basis of spatial separation of the areas and the relationships between grazing intensity and bird species composition within the areas, two of the areas were considered separate subregions.

The first subregion recognized from group 10 plots coincided with foothills grasslands at elevations $>1200 \mathrm{~m}$ in the Rocky Mountains and nearby outlying mountain ranges in Montana. Group 10 plots falling in the foothills were considered the heavily and moderately grazed representatives of these grasslands, and plots from group 8 that also fell in the foothills represented those with lesser amounts of herbage removal. These plots were combined to form the Foothills subregion shown in Fig. 6. Table 1 shows that the Foothills avifauna differs in many respects from those of the adjacent Northern and Transition subregions.

The second subgroup of plots from group 10 was clustered in southeastern Wyoming and northern Colorado. This general area was also considered a distinct subregion because it showed little spatial overlap with either the Eastern or Transition subregions and differed greatly from them in species composition and abundance (Table 1). The three grazing intensities tended to be more evenly represented in this subgroup than in the other subgroups of group 10, which further indicated ecological distinctiveness. The area occupied by this subgroup was designated the Southern subregion (Fig. 6).

The area occupied by the third subgroup of group 10 plots mostly overlapped the area of the central and western portions of the Northern subregion and was considered part of it. Heavily and moderately grazed plots in the western portion of this subregion tended to have larger proportions of McCown's than chestnut-collared longspurs; longspur populations in the central portion were more evenly distributed between the two species, and plots in the eastern portion were strongly dominated by chestnutcollared longspur (see Fig. 6).

\section{Characterization of subregions}

The effects of grazing on species composition, density and richness is shown for the six subregions in Table 1. Species richness tended to increase on moderately grazed plots and was highest on such plots in the Northern subregion and lowest under heavy grazing in the Southern subregion. Indeed, if we consider the series Southern-Shrubsteppe-Transition-Northern (Fig. 6) to represent best the longest south-north gradient through the study area, a pattern of increased species richness with latitude is revealed that holds for all grazing intensities. Cook (1969) and Peterson (1975) found similar patterns in this general area although it was not evident in Short's (1979) study. However, the pattern is also consistent with our earlier proposition (Kantrud \& Kologiski, 1982) that increased soil temperature limits species richness in the central Great Plains grasslands. Total bird density was more variable; it increased with heavy grazing in the Eastern, Northern and Transition subregions, with moderate grazing in the Foothills, and with light grazing in the more arid Southern 


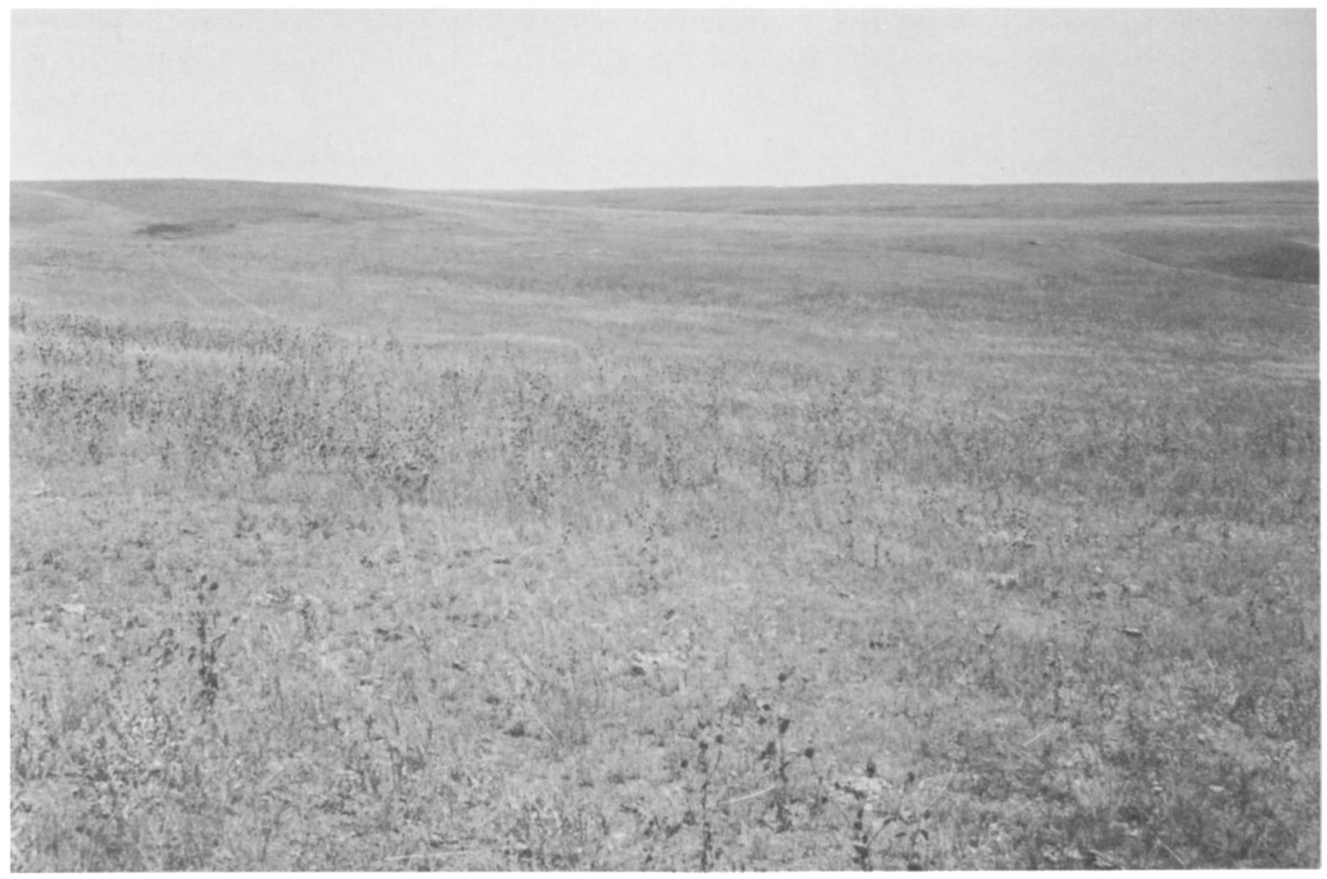

FIG. 7. Moderately grazed plot in the Eastern subregion (Dewey Co., SD).

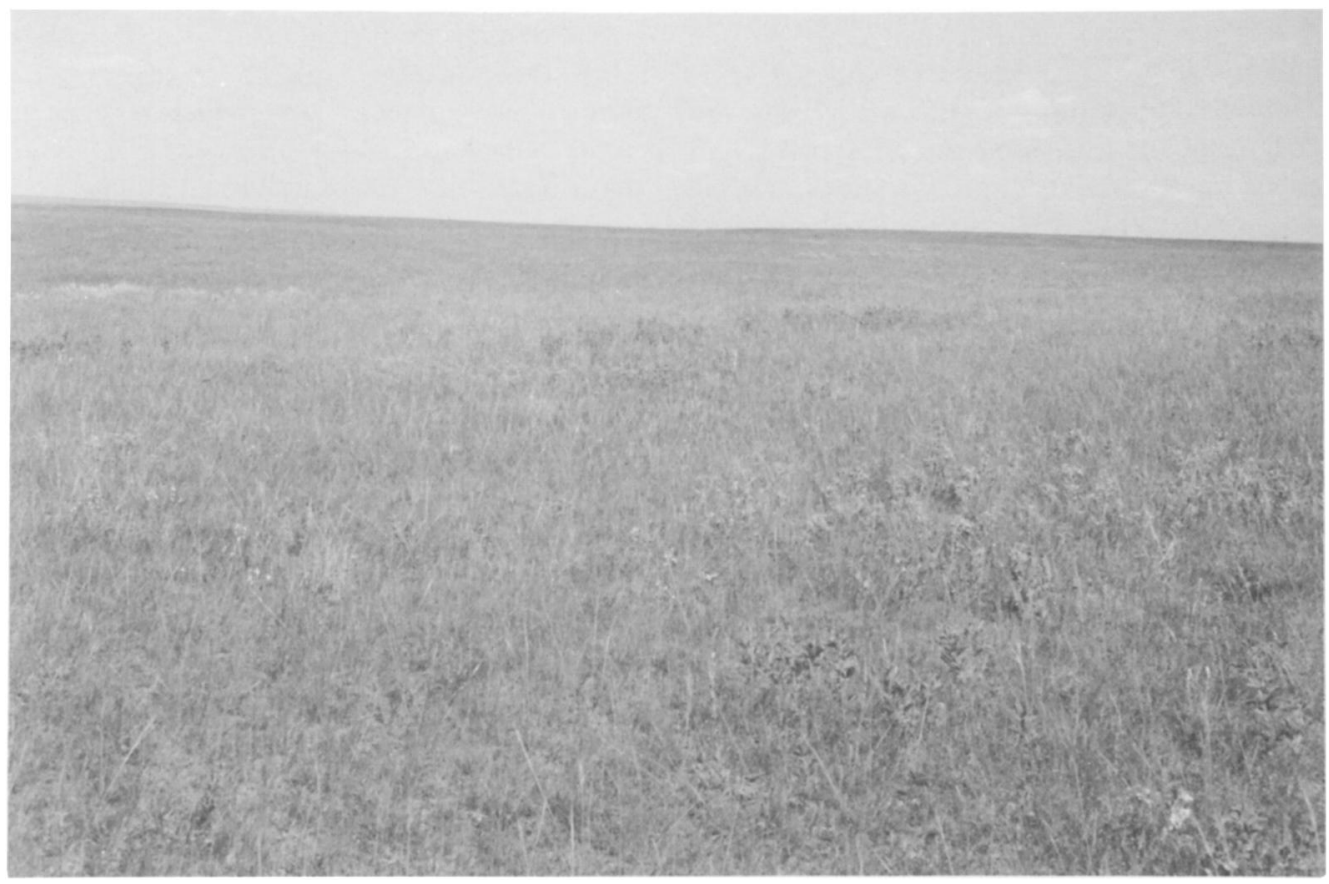

FIG. 8. Moderately grazed plot in the Northern subregion (Daniels Co., MT). 


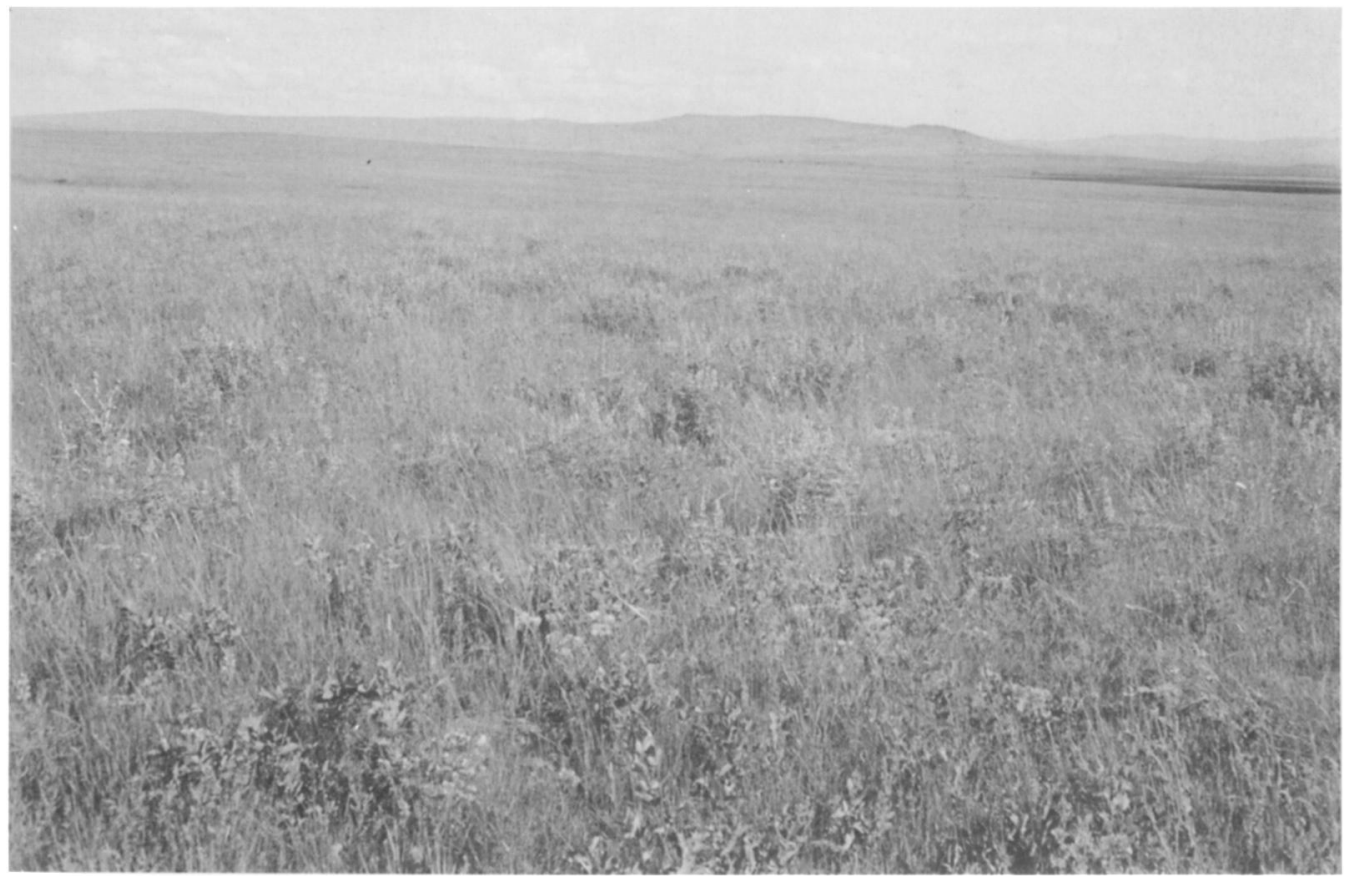

FIG. 9. Moderately grazed plot in the Foothills subregion (Cascade Co., MT).

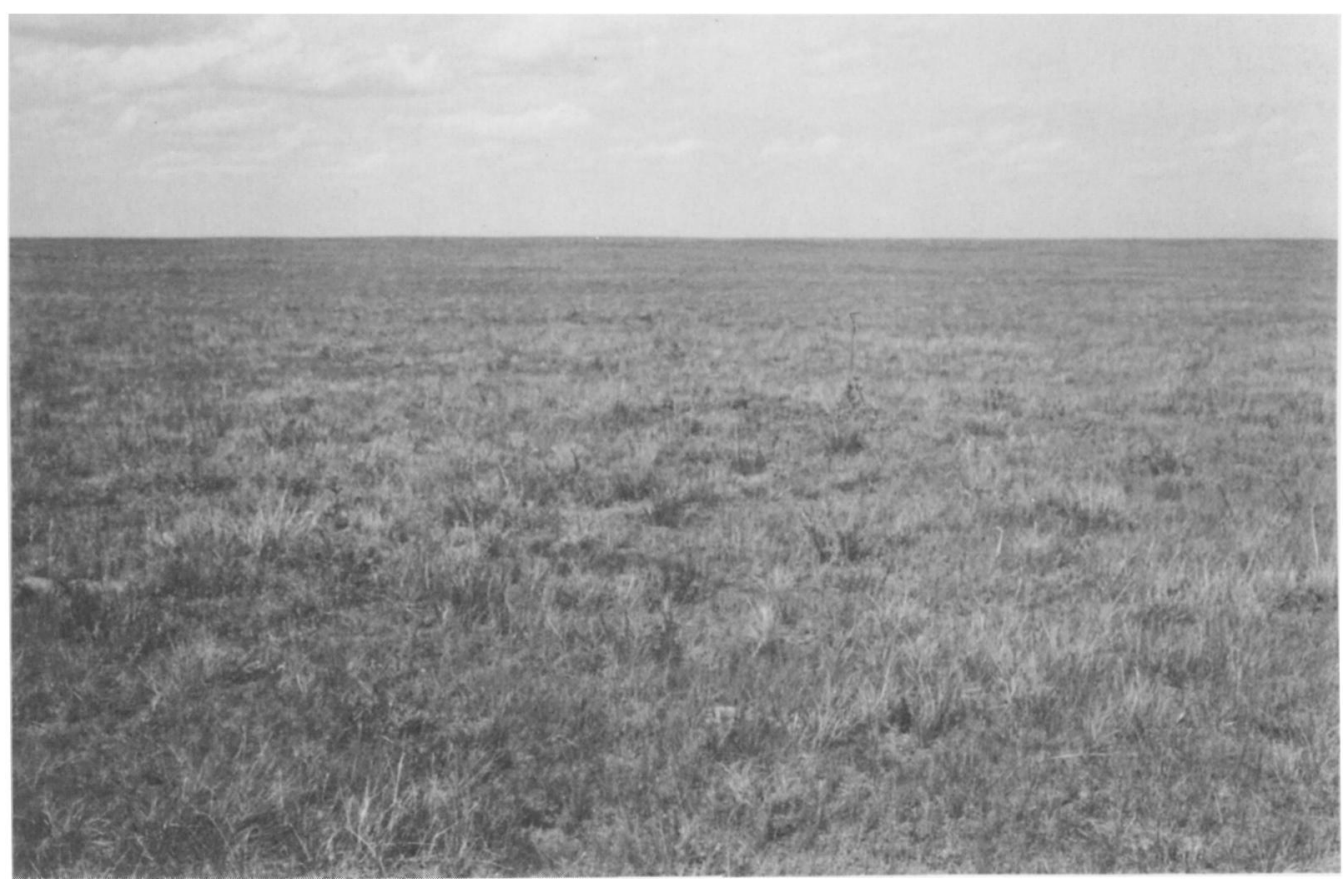

FIG. 10. Moderately grazed plot in the Southern subregion (Laramie Co., WY). 


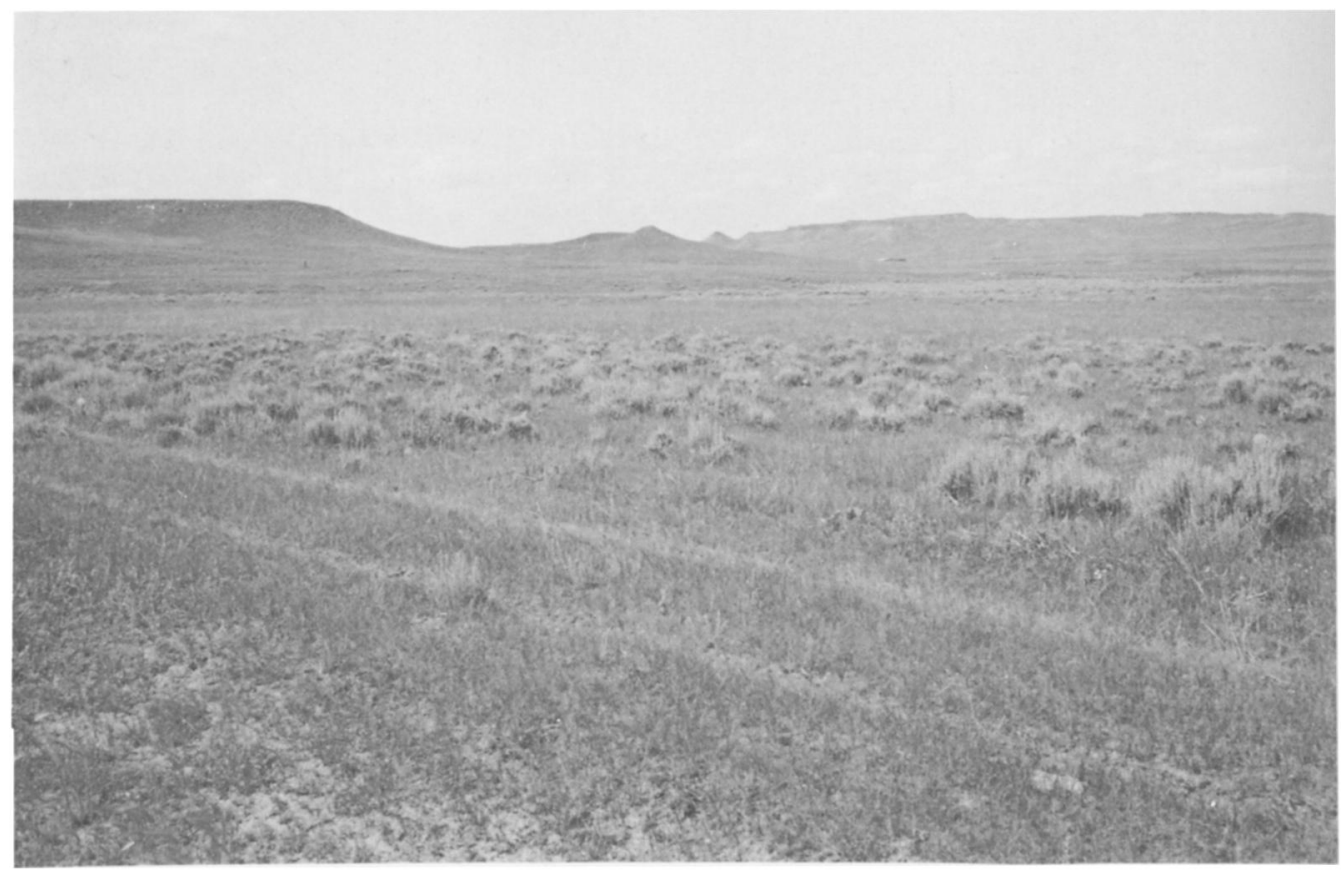

FIG. 11. Moderately grazed plot in the Transition subregion (Garfield Co., MT).

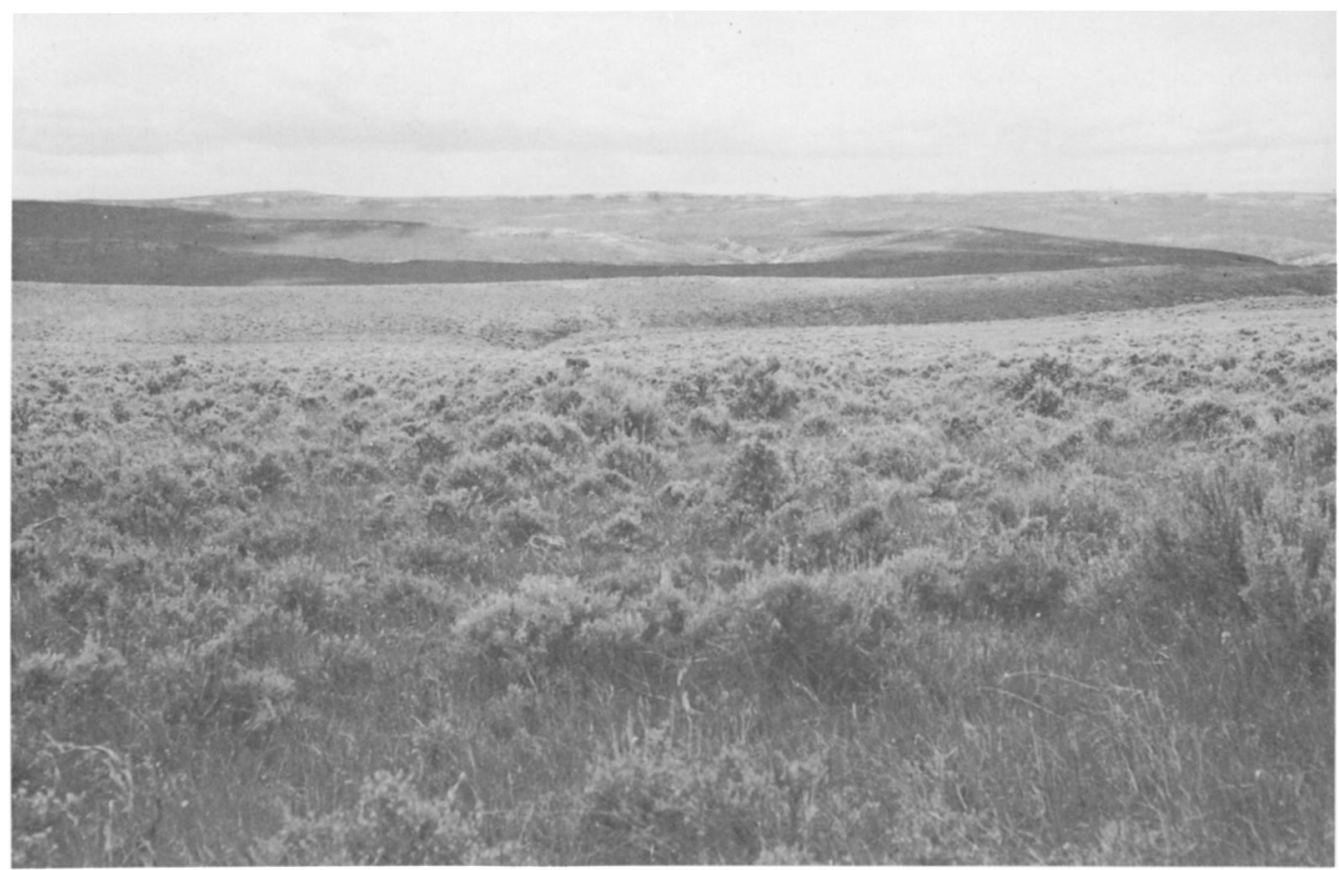

FIG. 12. Moderately grazed plot in the Shrubsteppe subregion (Johnson Co., WY). 
and Shrubsteppe subregions. Highest bird density occurred among heavily grazed plots in the Northern subregion, mostly because of their attractiveness to large numbers of horned lark and longspurs. Lowest density occurred on heavily grazed plots in the Shrubsteppe subregion.

Dominant bird species varied among the combinations of subregion and grazing intensity although aggregate numbers of the ubiquitous horned lark and western meadowlark always made up $19-61 \%$ of the population. In the Eastern and Northern subregions, chestnut-collared longspur was the most abundant species under all grazing intensities, whereas in the Foothills and Southern subregions, highest densities were generally shared by horned lark and McCown's longspur. In the Shrubsteppe subregion, western meadowlark and Brewer's sparrow predominated under light grazing but horned lark and Brewer's sparrow were most numerous when grazing was moderate or heavy. The Transition was the only subregion where western meadowlark was the most abundant bird in lightly and moderately grazed plots; horned lark and lark bunting were more numerous there when grazing was heavy.

The two most ecologically restricted species were mountain plover, with high populations confined to heavily grazed plots in the Southern subregion, and common yellowthroat, which attained high density only on lightly grazed plots in the Northern subregion. Other species which tolerated a rather narrow range of upland habitat in the northern Great Plains grasslands included bobolink, redwinged blackbird and clay-coloured sparrow.

Relations among breeding birds, grazing intensity, vegetation and soils have been reported in detail elsewhere (Kantrud \& Kologiski, 1982), but general preferences of some species for certain grazing intensities are also presented here. These preferences are listed by grazing intensity as follows: light: common yellowthroat, bobolink, western meadowlark and grasshopper, Baird's and clay-coloured sparrows; light or moderate: Sprague's pipit and savannah and vesper sparrows; moderate or heavy: Brewer's blackbird; heavy: mountain plover, burrowing owl and horned lark.

Several common species seemingly re- sponded differently to grazing among the subregions. Numbers of lark bunting were highest where grazing was moderate in the Eastern and Northern subregions, light in the Southern and Shrubsteppe, and heavy in the Transition. McCown's longspur probably attained peak density where grazing was heavy in the Northern, Foothills and Transition subregions but in the Southern and Shrubsteppe subregions they were likely most numerous where grazing was moderate. In areas of the Shrubsteppe where Artemisia tridentata dominated the vegetation of the general landscape, isolated breeding colonies of McCown's longspur were found at slightly higher elevations where the much shorter A. pedatifida was a dominant plant. Chestnutcollared longspurs were most numerous under heavy grazing in all subregions where they were common except the Foothills, where peak populations were found under moderately grazed conditions, and the Southern, where lightly grazed plots supported highest densities.

Relatively few sets of well co-distributed species were evident among the subregions. The largest group included sharp-tailed grouse, upland sandpiper, Brewer's blackbird, brownheaded cowbird and Brewer's sparrow which occurred in all subregions except the Southern. The group containing Sprague's pipit, savannah sparrow and Baird's sparrow was restricted to the Eastern, Northern and Foothills. Bobolink, red-winged blackbird and clay-coloured sparrow formed a group in the Eastern and Northern subregions. These groups would undoubtedly have changed if other habitats or plots of only a single grazing intensity had been included in the surveys, or if some obviously outlying sample plots had not been excluded when drawing the subregion boundaries. Even though the species in these groups accounted for $38 \%$ of the species censused, some common species (e.g. upland sandpiper and Brewer's sparrow) that were of high indicator value in different subregions showed co-distribution. It is likely that the Eastern subregion, as delineated, contained just enough suitable habitat on lightly grazed plots on its western edge to attract a few Brewer's sparrows while small numbers of upland sandpiper occurred on lightly and moderately grazed Shrubsteppe. Other species 
such as mountain plover and common yellowthroat occupied only a small portion of their respective subregion(s).

Mengel (1970) characterized the plains grasslands as an area of few endemic species that acted as a barrier during glaciation and allowed greater speciation within the complex amalgam of forest, woodland and assorted scrub avifaunas arranged around it in a crudely circular pattern. This concept agrees well with the results of our study. Thus, we found no internal avian associations, even at this relatively large scale. In addition, the breeding ranges of many species which reached highest density in, or were indicative of, our subregions encompass large areas adjacent to the subregions, but outside the study area. Examples of this pattern include the large breeding ranges for Sprague's pipit, savannah sparrow, Baird's sparrow, and the two longspurs that lie to the north of our Northern subregion, and for sage grouse, mountain plover, burrowing owl, sage thrasher and Brewer's sparrow that lie to the south or west of our Shrubsteppe subregion.

Our findings further illustrate the importance of scale in community studies. Wiens \& Rotenberry (1981) have pointed out how evolutionary and biogeographic influences apparent at large geographic scales can be minimized at regional or local scales. Highest level division of our indicator species analysis (closest to any possible 'continental' scale) differentiated avian associations of the 'pure' grasslands from those of the Shrubsteppe and Transition subregions. Even though there are great physiognomic differences in the vegetation, there were several shrub-nesters on the grassland 'side' of the TWINSPAN analysis and an assortment of ground-nesters on the shrubsteppe 'side'. The initial division separated the areas most widely disparate in soils, climate and vegetation. Therefore, this division could also be considered a separation on the basis of evolutionary adaptation to essentially different general environments. Shrubnesting species in the Northern subregion such as the clay-coloured sparrow and common yellowthroat seem poorly adapted, as evidenced by their sensitivity to grazing, limited use of grasslands in general, and use for nest sites of only a few of the shrub species that occur in grasslands. Second and third level divisions in our analysis likely reflected the vegetational structures used for nesting and foraging. Our earlier analysis (Kantrud \& Kologiski, 1982) indicated that, among the subregions, bird densities and species composition varied greatly within grazing intensities due to the regional occurrence of grasslands differing naturally in height and the percentage of bare soil. Yet the grasslands exist as a patchy mosaic of variously grazed plots and, at the local scale, differences in grazing intensity within subregions obviously had profound effects on the density and even the occurrence of some species.

Finally, the validity of our avian subregions seems reinforced by their coincidence with mapped units of soils and vegetation. The avian subregions (Fig. 6) roughly overlap with the areas occupied by the major soils in the study area (Fig. 2). Especially noticeable is the relationship between the cool moist borolls and the Northern and Foothills subregions and between the warm dry Aridisols and the combined Shrubsteppe and Transition subregions. The boundaries of the Northern subregion also match well with the mapped boundaries of the grasslands of the Brown Soil Zone in adjacent Canada (Campbell et al., 1962). In Montana, the Northern subregion corresponds to the Glaciated Plains Zones of Ross \& Hunter (1976).

Some of the subregions coincide fairly closely with phytogeographic areas, especially those classified and mapped by Schantz (1923). Overlap of our subregions with the largest units of potential vegetation mapped by Küchler (1964) is not great; however, his foothills prairie (Agropyron-Festuca-Stipa). and grama-buffalograss (Bouteloua-Buchloe) associations obviously correspond to our Foothills and Southern subregions. Strict comparisons of our subregions with Küchler's (1964) phytogeographic units are difficult because of modifications to the original vegetation caused by fire suppression, range deterioration, introduced plants, and other factors. For example, the shrub Artemisia tridentata increases greatly (Fig. 12) across much of the southern portions of Küchler's (1976) grama-needlegrass-wheatgrass (Bouteloua-Stipa-Agropyron) type in Wyoming (U.S. Department of Agriculture, 1966).

In conclusion, we believe that future biogeographical studies at the community level 
will be of greatest value to science if based on quantitative measurements of carefully selected species. A general knowledge of species ecology also seems mandatory. The usefulness of such studies probably will increase if conservationists adopt biogeographic regions rather than political or administrative subdivisions in their efforts to protect natural areas (Axtell, 1962). Biogeographical information may be especially helpful in instances where conservation efforts involve superficially homogeneous communities that occupy large areas, because in regions undergoing rapid resource development, it is often necessary that programmes to protect natural areas be directed toward preservation of representative biocenoses rather than habitat for individual species.

\section{Acknowledgments}

R. E. Stewart participated in and was responsible for the first 2 years of field work. We also received ornithological assistance in the field from B. A. Barnes, C. A. Faanes, B. A. Hanson and J. T. Lokemoen, and botanical assistance from L. M. Cowardin, D. S. Gilmer and A. T. Klett. D. Alan Davenport, A. M. Frank and D. H. Johnson conducted computer programming and statistical analyses. We thank A. M. Frank and T. R. Wentworth for reviewing the manuscript. The study was supported by the U.S. Fish and Wildlife Service through the Migratory Birds Program and the Coal Project, Western Energy Land Use Team, Office of Biological Services.

\section{References}

Aandahl, A.R. (1972) Soils of the Great Plains. [Map]. A. R. Aandahl, P.O. Box 81242, Lincoln, Nebraska 68508.

American Ornithologists' Union (1957) Check-list of North American birds, 5th edn. (suppl.). American Ornithologists' Union, Baltimore.

Axtell, R.W. (1962) Can we use biotic provinces? Syst. Zool. 11, 93-96.

Bluemle, J.P. (1977) The face of North-Dakota the geologic story. N.D. Geol. Surv. Educ. Ser. 11.

Bock, C.E., Bock, J.H. \& Lepthien, L.W. (1977) Abundance patterns of some bird species wintering on the Great Plains of the U.S.A. J. Biogeogr. 4, 101-110.
Cain, S.A. (1947) Characteristics of natural areas and factors in their development. Ecol. Monogr. 17, 185-200.

Campbell, J.W., Lodge, R.W., Johnston, A. \& Smoliak, S. (1962) Range management of grasslands and adjacent parklands in the prairie provinces. Can. Dep. Agric. Publ. 1133.

Cook, R.E. (1969) Variation in species density of North American birds. Syst. Zool. 18, 63-84.

Dice, L.R. (1930) Methods of indicating relative abundance of birds. $A u k, 47,22-24$.

Dice, L.R. (1952) Natural communities. University of Michigan Press, Ann Arbor.

Fenneman, N.M. (1931) Physiography of western United States. McGraw-Hill, New York.

Frenkel, R.E. \& Harrison, C.M. (1974) An assessment of the usefulness of phytosociological and numerical classificatory methods for the community biogeographer. J. Biogeogr. 1, 27-56.

Grinnell, J. \& Storer, T. I. (1924) Animal life in the Yosemite. University of California Press, Berkeley.

Hagemeier, E.M. \& Stults, C.D. (1964) A numerical analysis of the distributional patterns of North American mammals. Syst. Zool. 13, 125-155.

Hill, M.O. (1973) Reciprocal averaging: an eigenvector method of ordination. J. Ecol. 61, 237249.

Hill, M.O. (1979) TWINSPAN - A computer program for arranging multivariate data in an ordered two-way table by classification of the individuals and attributes. Cornell University, Ithaca, New York.

Hill, M.O., Bunce, R.G.H. \& Shaw, M.W. (1975) Indicator species analysis, a divisive polythetic method of classification, and its application to a survey of native pinewoods in Scotland. J. Ecol. $63,597-613$.

Kantrud, H.A. (1981) Grazing intensity affects the breeding avifauna of North Dakota native grasslands. Can. Field-Nat. 95, 404-417.

Kantrud, H.A. (1982) Maps of distribution and abundance of selected species of birds on uncultivated native upland grasslands and shrubsteppe in the northern Great Plains. U.S. Fish Wildl. Serv. FWS/OBS-82/31.

Kantrud, H.A. \& Kologiski, R.L. (1982) Effects of soils and grazing on breeding birds of uncultivated upland grasslands of the northern Great Plains. U.S. Fish Wildl. Serv. Wildl. Res. Rep. 15.

Küchler, A.W. (1964) Potential natural vegetation of the conterminous United States. Am. Geogr. Soc., New York.

MacArthur, R.H. (1972) Geographical ecology. Patterns in the distribution of species. Harper \& Row, New York.

Mengel, R.M. (1970) The North American central plains as an isolating agent in bird speciation. Pleistocene and recent environments of the central Great Plains (ed. by W. Dort, Jr and J. K. Jones, Jr), pp. 279-340. University of Kansas Dep. Geol. Spec. Publ. 3.

Mueller-Dombois, D. \& Ellenberg, H. (1974) Aims and methods of vegetation ecology. John Wiley, New York. 
Peters, J.A. (1955) Use and misuse of the biotic province concept. Am. Nat. 89, 21-28.

Peterson, S.R. (1975) Ecological distribution of breeding birds. Symposium on management of forest and range habitats for nongame birds (comp. by D. R. Smith), pp. 22-38. U.S. For. Serv. Gen. Tech. Rep. W0-1.

Robbins, C.S. \& Van Velzen, W.T. (1967) The breeding bird survey, 1966. U.S. Fish Wildl. Serv. Spec. Sci. Rep. Wildl. 102.

Rodgers, W.A., Owen, C.F. \& Homewood, K.M. (1982) Biogeography of East African forest mammals. J. Biogeogr. 9, 41-54.

Ross, R.L. \& Hunter, H.E. (1976) Climax vegetation of Montana based on soils and climate. U.S. Dep. Agric., Soil Cons. Serv., Bozeman, Montana.

Rotenberry, J.T. (1978) Components of avian diversity along a multifactorial climatic gradient. Ecology, 59, 693-699.

Rotenberry, J.T. \& Wiens, J.A. (1978) Nongame bird communities in northwestern rangelands. Workshop on nongame bird habitat management in coniferous forests of western United States (comp. by R. M. DeGraaf), pp. 32-46. U.S. For. Serv. Gen. Tech. Rep. PNW-64.

Rotenberry, J.T. \& Wiens, J.A. (1980) Habitat structure, patchiness, and avian communities in North American steppe vegetation: a multivariate analysis. Ecology, 61, 1228-1250.

Rotramel, G.L.(1973) The development and application of the area concept in biogeography. Syst. Zool. 22, 227-232.

Saunders, A.A. (1921) A distributional list of the birds of Montana, with notes on the migration and nesting of the better known species. Pac. Coast Avifauna 14.

Schantz, H.L. (1923) The natural vegetation of the Great Plains. Ann. Assoc. Amer. Geographers, 13, 81-107.

Short, J.J. (1979) Patterns of alpha-diversity and abundance in breeding bird communities across North America. Condor, 81, 21-27.
Skinner, R.M. (1975) Grassland use patterns and prairie bird populations in Missouri. Prairie: $a$ multiple view (ed. by M. K. Wali), pp. 171-180. University of North Dakota Press, Grand Forks.

Speirs, J.M. \& Orenstein, R. (1967) Bird populations in fields of Ontario County, 1965. Can. Field-Nat. 81, 175-183.

Stewart, R.E. (1975) Breeding birds of North Dakota. Tri-college Center for Environmental Studies, Fargo, N.D.

Stewart, R.E. \& Kantrud, H.A. (1972) Population estimates of breeding birds in North Dakota. Auk, 89, 766-788.

Udvardy, M.D.F. (1963) Bird faunas of North America. Int. Ornithol. Congr. 13, 1147-1167.

Udvardy, M.D.F. (1969) Dynamic zoogeography. Van Nostrand Reinhold, New York.

U.S. Department of Agriculture (1966) Technical range site descriptions, Wyoming. U.S. Dep. Agric., Soils Cons. Serv., Casper, Wyoming.

U.S. Department of the Interior and Canadian Department of the Environment (1977) Standard operating procedures for aerial waterfowl breeding ground population and habitat surveys, Section IV.

U.S. Soil Conservation Service. Soil Survey Staff. (1975) Soil taxonomy. U.S. Dep. Agric. Handb. 436.

Visher, S.S. (1916) The biogeography of the northern Great Plains. Geogr. Rev. 2, 89-115.

Visher, S.S. (1918) The geography of South Dakota; a detailed discussion of the surface, resources, climate, plants, animals, and human geography, including the history of the area. S.D. Geol. Nat. Hist. Surv. Bull. 8.

Wiens, J.A. \& Rotenberry, J.T. (1981) Habitat associations and community structure of birds in shrubsteppe environments. Ecol. Monogr. 51, $21-41$. 